\title{
Influence of structural factors on physico-chemical properties of glasses and glass coatings in alkalialumoborosilicate system
}

\author{
O.Shalygina, G.Voronov, G.Tymoshenko (Mironova), A.Odintsova \\ National Technical University "Kharkiv Polytechnic Institute", \\ 21 Frunze Str., 61002 Kharkiv, Ukraine
}

Received January 27, 2016

\begin{abstract}
It was revealed the degree of impact of structural factors on physical and chemical properties of glasses and glass coatings, particularly chemical resistance, water resistance, surface-tension of and spreading in the $\mathrm{R}_{2} \mathrm{O}-\mathrm{R}^{\prime} \mathrm{O}-\mathrm{Al}_{2} \mathrm{O}_{3}-\mathrm{B}_{2} \mathrm{O}_{3}-\mathrm{SiO}_{2}$ system. It was determined clear boundaries of the values of the structural factors and their relationship with the glass chemical composition. The basic principles of synthesis of multifunctional glass matrices - bases of chemically resistant fusible glass coating were developed.

Keywords: glass matrices, structural factors, chemical resistance, glass-coated texture glass, multifunctionality.
\end{abstract}

Установлена степень влияния структурных факторов на физико-химические свойства стекол и стеклопокрытий, в частности химическую стойкость, водостойкость, поверхностное натяжение и растекание, в системе $\mathrm{R}_{2} \mathrm{O}-\mathrm{R}^{\prime} \mathrm{O}-\mathrm{Al}_{2} \mathrm{O}_{3}-\mathrm{B}_{2} \mathrm{O}_{3}-\mathrm{SiO}_{2}$, определены четкие границы значений структурных факторов и их взаимосвязь с химическим составом стекол. Разработаны основные принципы синтеза полифункциональной стекломатрицы - основы химически стойких легкоплавких стеклоэмалевых покрытий.

Вплив структурних факторів на фізико-хімічні властивості стекол та склопокриттів у лужноалюмоборосилікатній системі. О.В. ШІалигіна, Г.К. Воронов, Г.И. Тимошенко (Миронова), А.П. Одинцова.

Встановлено ступінь впливу структурних факторів на фізико-хімічні властивості стекол і склопокриттів, зокрема хімічну стійкість, водостійкість, поверхневий натяг $\mathrm{i}$ розтікання, в системі $\mathrm{R}_{2} \mathrm{O}-\mathrm{R}^{\prime} \mathrm{O}-\mathrm{Al}_{2} \mathrm{O}_{3}-\mathrm{B}_{2} \mathrm{O}_{3}-\mathrm{SiO}_{2}$, визначено чіткі межі значень структурних факторів та їх взаємозв'язок із хімічним складом стекол. Розроблено основні принципи синтезу поліфункціональної скломатриці - основи хімічно стійких легкоплавких склоемалевих покриттів.

\section{Introduction}

Glasses of $\mathrm{R}_{2} \mathrm{O}-\mathrm{R}^{\prime} \mathrm{O}-\mathrm{Al}_{2} \mathrm{O}_{3}-\mathrm{B}_{2} \mathrm{O}_{3}-\mathrm{SiO}_{2}$ system, in which $\left[\mathrm{R}_{2} \mathrm{O}\left(\sum \mathrm{Na}_{2} \mathrm{O}, \mathrm{K}_{2} \mathrm{O}\right)-\mathrm{R}^{\prime} \mathrm{O}\left(\sum \mathrm{CaO}, \mathrm{BaO}\right)\right]$ are the basis of almost all glass-protective coatings for steel, that are widely used in production of heating equipment and appliances, pipes for hot water supply and petrochemical industry, heat exchange units, containers for the food and chemical industry, agriculture, and others [1]. Scope of their applications determines the range of performance properties of the coatings, which must be considered in the development of vitreous enamel compositions [2,3]. The most developing area of the enamelled products market is production of household heating equipment, the most important of which is the property of chemical resis- 
tance, which determines the ability to resist the effects of various agents [2,4]. Development and application of the low-melting direct-on chemically resistant coatings applied by electrostatic powder technology POESTA (Powder Electrostatic Application), by reducing energy and resource consumption increases the competitiveness of the enamelled products as compared to conventional two-layer coatings.

The aim of the study is to develop a content of the multifunctional glass matrix (MFGM) - the basis of fusible glass-chemically resistant coatings obtained by energy saving technology POESTA. Developed glass matrice defines the basic physical and chemical properties of the coating material - glass-powder and performance of the coatings obtained on its basis and the introduction of components that provide the color and strength characteristics of the coating.

To achieve this goal, taking into account the requirements in terms of performance coatings, physical and chemical properties of the frits and powders of these (Table 1), the following research areas are defined:

- establishment of criteria for synthesis parameters of glass matrix - bases frits and coatings;

- determination of the composition range of glass matrix (model glasses) with the given values of criteria parameters;

- determination of the effect of structural factors on the physico-chemical and performance properties of glass matrix.

\section{Experimental}

\subsection{Determination of criteria parameters}

For design of the multifunctional glassmatrix (MFGM) composition - the basis of fusible direct-on chemically resistant protective coatings applied for technology POESTA, the values of criteria defined properties and settings, which should match the characteristics MFGM (model glasses), frits and coatings, were determined. On the basis of existing international industry regulations [5] and the technological process parameters the values of criteria are set (see Table 1). The most important technical characteristics of the glass and vitreous enamels are melting temperature and coatings firing temperature. These mentioned limits to the values of these characteristics (Table 1) depends on homogenization temperature of alkalialumoborosilicate glass melt, production conditions and technological parameters of melting equipment, as well as on the need for energy saving.

Obtaining uniform defect-free coating is largely dependent on the surface tension of glass melt, which actually defines the wetting process of the metal base by melt, significantly affects the intensity of the process of degasification and clarification. In particular, it removes the gas bubbles from the melt during the enamels melting and the gas phase formed at the contact border "metal - enamel".

Significant role in the preparation of the protective coating has a ratio of the temperature coefficients of linear expansion (coefficient of linear expansion) of the metal and glass coatings. Improperly selected ratio is the primary cause of permanent stresses in the system metal-coating.

Application of the vitreous enamel coating by the POESTA technology demands the high values of specific resistivity of the glass matrix, namely $\rho>10^{8} \Omega \cdot \mathrm{m}$.

Chemical resistance of the MFGM - the basis of protective coatings, is one of the main technical characteristics.

2.2. Development of glass matrix composition (model glasses)

Using the theoretical principles as the basis for synthesis of the low-melting chemically resistant glass with high values of specific resistivity it was chosen system

Table 1. Criterion parameters of glassmatrix, frits and coatings on their basis

\begin{tabular}{|c|c||}
\hline Parameter & Indicator \\
\hline The temperature melting glass-enamel, $T_{\text {melting }},{ }^{\circ} \mathrm{C}$ & $\leq 1300$ \\
Firing temperature coatings, $T_{\text {firing }},{ }^{\circ} \mathrm{C}$ & $820-840$ \\
Surface tension of the melt, $\sigma, \mathrm{mN} / \mathrm{m}$ & $280-310$ \\
Temperature coefficient of linear expansion (TCLE), $\alpha \cdot 10^{7}$, degree $^{-1}$ & $80-120$ \\
Own electrical resistivity of glass-enamel powder, $\rho, \Omega \cdot \mathrm{m}$ & $\geq 10^{8}$ \\
Chemical resistance of the coating, (ISO $28706: 2008)$, class & AA, A \\
The propensity to crystallization & absence \\
\hline \hline
\end{tabular}


$\mathrm{R}_{2} \mathrm{O} \quad\left(\sum \mathrm{Na}_{2} \mathrm{O}, \quad \mathrm{K}_{2} \mathrm{O}\right)-\mathrm{R}^{\prime} \mathrm{O}\left(\sum \mathrm{CaO}, \mathrm{BaO}\right)-$ $\mathrm{Al}_{2} \mathrm{O}_{3}-\mathrm{B}_{2} \mathrm{O}_{3}-\mathrm{SiO}_{2}$ with the following ratio of components $\mathrm{Na}_{2} \mathrm{O}: \mathrm{K}_{2} \mathrm{O}=2: 1$ and $\mathrm{CaO}: \mathrm{BaO}=$ $3: 1, \mathrm{R}_{2} \mathrm{O}: \mathrm{R}^{\prime} \mathrm{O}=2: 1[1,4]$.

At the system and content of its components selection it was taken into account the data on the effect of complex silicate oxide system on the structure and properties of the glasses and it was set the criteria parameters, ensuring to achieve direct control of the chemical composition.

In order to obtain the MFGM with a given set of parameters (Table 1) the method of optimal experiment - simplexlattice planning was used [6]. Factor space with the number $n=3$ is system in which the consistency of quantity $\mathrm{SiO}_{2}$ (content $60 \mathrm{~mol}$. \%) geometrically transforms system $\mathrm{R}_{2} \mathrm{O}\left(\sum \mathrm{Na}_{2} \mathrm{O}, \mathrm{K}_{2} \mathrm{O}\right)-\mathrm{R}^{\prime} \mathrm{O}\left(\sum \mathrm{CaO}, \mathrm{BaO}\right)$ $-\mathrm{Al}_{2} \mathrm{O}_{3}-\mathrm{B}_{2} \mathrm{O}_{3}-\mathrm{SiO}_{2}$ in the plane, i.e. in pseudoternary $\mathrm{R}_{2} \mathrm{O}\left(\sum \mathrm{Na}_{2} \mathrm{O}, \mathrm{K}_{2} \mathrm{O}\right)-\mathrm{R}^{\prime} \mathrm{O}\left(\sum\right.$ $\mathrm{CaO}, \mathrm{BaO})-\mathrm{Al}_{2} \mathrm{O}_{3}-\mathrm{B}_{2} \mathrm{O}_{3}$. It was built four simplex diagrams of the complete cube model based on developed values of criteria properties (melting temperature, surface tension, coefficient of linear expansion and resistivity) on the chemical composition, the mutual imposition of which 8 experimental model of glass compositions (MG) - glass matrix are defined (Fig. 1).

Calculation of criteria properties hold with using of the additive methods $[7,8]$. Further optimization of the composition of the MFGM conducted on the model glasses, the compositions of which were located in the selection of the optimum.

To confirm the computed data on the theoretical possibility of using 8 compositions of MG as MFGM - fusible bases chemically resistant coatings, conducted their laboratory melting and determination of physical-chemical, operational and technological properties. It was established experimentally that the specified boundaries of melting temperature of the glass $\left(\leq 1300^{\circ} \mathrm{C}\right)$ corresponded to the compositions of MG 3, MG 4, MG 5 and MG 6. Melting temperatures of MG 1, MG 2, MG 7 and MG 8 were significantly higher than specified to $1300^{\circ} \mathrm{C}$. All modeling glass were obtained by the method of granulation of glass melt.

2.3. Determination of influence of structural factors on physico-chemical and performance properties of glass matrix

Physico-chemical and performance properties of silicate glasses and glass coatings

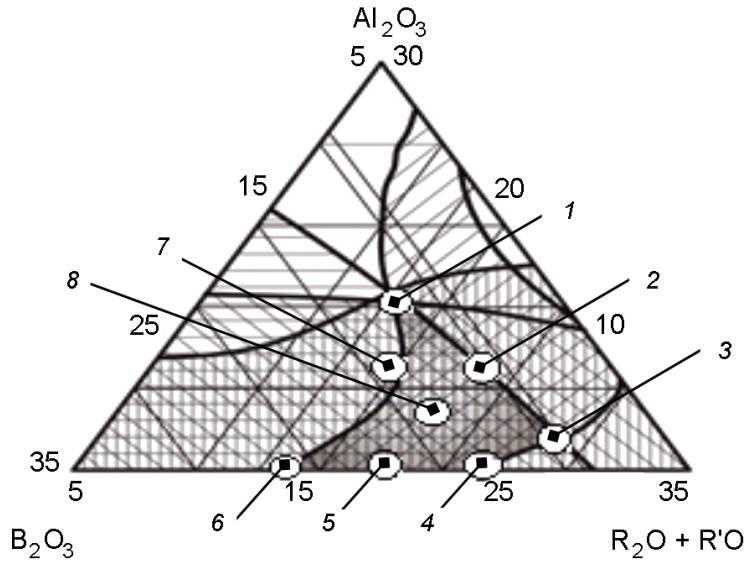

Fig. 1. Diagram of criterion parameters of MFGM on chemical composition of the compositions with points of model glasses.

are functions of structural strength of the frame, which is characterized by the values of structural factors: degree of connectedness of silicon-oxygen frame $f_{\mathrm{Si}}(1)$ and coefficient $\psi_{B}$ (points to the coordination state of glass former - cations) (2). Degree of connectivity $f_{\mathrm{Si}}$ is determined by the ratio of silicon atoms (glass former) to the number of oxygen atoms Si/O. Chemically resistant fusible silicate glasses should be characterized by the values of coefficient $f_{\mathrm{Si}}$ within $0.3-0.35[9,10]$ :

$$
=\frac{f_{\mathrm{Si}}=}{\gamma_{\mathrm{SiO}_{2}}} \frac{1}{\gamma_{\mathrm{R}_{2} \mathrm{O}}+\gamma_{\mathrm{R}_{2} \mathrm{O}}+3 \gamma_{\mathrm{R}_{2} \mathrm{O}_{3}}+2 \gamma_{\mathrm{RO}_{2}}+5 \gamma_{\mathrm{R}_{2} \mathrm{O}_{5}}+3 \gamma_{\mathrm{RO}_{3}}},
$$

where $\gamma-$ content of oxides in the glass in mole parts.

In alkalialumoborosilicate the glass structural strength of its frame is determined by the state coordinating cations $\mathrm{Si}^{4+}, \mathrm{B}^{3+}, \mathrm{Al}^{4+}$. The highest degree of structural strength of the carcass is achieved in the case of quaternary coordinate boron and aluminum, for the existence of which in a tetrahedral environment it is needed the particular relationship between concentration of the modifier (oxygen donors) and oxides of $\mathrm{Al}_{2} \mathrm{O}_{3}$ and $\mathrm{B}_{2} \mathrm{O}_{3}$. In the case of silicate glass in excess of the active oxygen carriers, which are introduced modifier $\mathrm{R}_{2} \mathrm{O}$ and $R^{\prime} O, B$ and $A l$ cations replace $S i$ in the glass structure and form single alumoborosilicooxygen structure. Estimation of transition probability $\mathrm{B}$ and $\mathrm{Al}$ in tetradic coordination is determined by an indicator of the structural factor $\psi_{B}$ (Table 2) [9]: 
O.Shalygina et al. / Influence of structural factors ...

Table 2. Chemical composition, properties and values of the structural factors of MG

\begin{tabular}{|c|c|c|c|c|c|c|c|c|}
\hline \multirow[t]{2}{*}{ Oxide } & \multicolumn{8}{|c|}{ The content of oxides, mol. $\%$} \\
\hline & MG 1 & MG 2 & MG 3 & MG 4 & MG 5 & MG 6 & MG 7 & MG 8 \\
\hline $\mathrm{SiO}_{2}$ & 60.0 & & & & & & & \\
\hline $\mathrm{B}_{2} \mathrm{O}_{3}$ & 13.0 & 12.0 & 13,0 & 15.0 & 20.0 & 25.0 & 15.0 & 15.0 \\
\hline $\mathrm{Al}_{2} \mathrm{O}_{3}$ & 12.0 & 8.0 & 2.0 & 0 & 0 & 0 & 8.0 & 5.0 \\
\hline $\mathrm{R}_{2} \mathrm{O}$ & 10.0 & 13.3 & 16.7 & 16.7 & 13.3 & 10.0 & 11.3 & 13.3 \\
\hline $\mathrm{R}^{\prime} \mathrm{O}$ & 5.0 & 6.7 & 8.3 & 8.3 & 6.7 & 5.0 & 5.7 & 6.7 \\
\hline \multicolumn{9}{|c|}{ Properties of model glasses MG } \\
\hline$T_{\text {melting }},{ }^{\circ} \mathrm{C}$ & 1301 & 1274 & 1198 & 1164 & 1108 & 1093 & 1292 & 1242 \\
\hline$\sigma, \mathrm{mN} / \mathrm{m}, 840^{\circ} \mathrm{C}$ & 334 & 312 & 308 & 294 & 254 & 247 & 309 & 291 \\
\hline$\alpha \cdot 10^{-7}$, degree $^{-}$ & 67 & 84 & 81 & 82 & 87 & 71 & 74 & 85 \\
\hline$\rho, \Omega \cdot \mathrm{m}$ & $10^{9.5}$ & $10^{9.7}$ & $10^{10.1}$ & $10^{9.9}$ & $10^{9.9}$ & $10^{10.2}$ & $10^{10.2}$ & $10^{9.3}$ \\
\hline Flowability, mm & 13.0 & 15.0 & 44.0 & 46.0 & 26.0 & 30.0 & 32.0 & 23.0 \\
\hline $\begin{array}{l}\text { Chemical resis- } \\
\text { tance, class }\end{array}$ & - & $\mathrm{A}+$ & AA & AA & - & - & - & - \\
\hline \multicolumn{9}{|c|}{ Water resistance: consumption $0.01 \mathrm{~N}$. $\mathrm{HCl}$ solution at titration $V, \mathrm{~cm}^{3} \cdot \mathrm{g}^{-1}, \mathrm{~cm}^{3} / \mathrm{g}$} \\
\hline Mains water & 9.1 & 5.8 & 5.1 & 5.2 & 6.4 & 6.7 & 8.7 & 5.4 \\
\hline Distilled water & 4.6 & 1.6 & 1.1 & 1.2 & 1.8 & 2.2 & 4.6 & 1.5 \\
\hline \multicolumn{9}{|c|}{ Structural indicators of model glasses } \\
\hline$\psi_{B}$ & 0.14 & 0.88 & 1.63 & 1.54 & 0.93 & 0.56 & 0.52 & 0.90 \\
\hline $\begin{array}{c}\text { Coordination state } \\
\text { of } \mathrm{B} \text { and } \mathrm{Al}\end{array}$ & $\begin{array}{l}{\left[\mathrm{AlO}_{4}\right]} \\
{\left[\mathrm{BO}_{3}\right]}\end{array}$ & $\begin{array}{c}{\left[\mathrm{AlO}_{4}\right]} \\
{\left[\mathrm{BO}_{3}\right]} \\
{\left[\mathrm{BO}_{4}\right]}\end{array}$ & $\begin{array}{c}{\left[\mathrm{AlO}_{4}\right]} \\
{\left[\mathrm{BO}_{4}\right]}\end{array}$ & $\begin{array}{l}{\left[\mathrm{AlO}_{4}\right]} \\
{\left[\mathrm{BO}_{4}\right]}\end{array}$ & $\begin{array}{l}{\left[\mathrm{AlO}_{4}\right]} \\
{\left[\mathrm{BO}_{4}\right]} \\
{\left[\mathrm{BO}_{3}\right]}\end{array}$ & $\begin{array}{l}{\left[\mathrm{AlO}_{4}\right],} \\
{\left[\mathrm{BO}_{4}\right],} \\
{\left[\mathrm{BO}_{3}\right]}\end{array}$ & $\begin{array}{c}{\left[\mathrm{AlO}_{4}\right],} \\
{\left[\mathrm{BO}_{4}\right],} \\
{\left[\mathrm{BO}_{3}\right]}\end{array}$ & $\begin{array}{l}{\left[\mathrm{AlO}_{4}\right],} \\
{\left[\mathrm{BO}_{4}\right],} \\
{\left[\mathrm{BO}_{3}\right]}\end{array}$ \\
\hline$f_{S i}$ & 0.29 & 0.30 & 0.32 & 0.32 & 0.30 & 0.29 & 0.29 & 0.30 \\
\hline$A P F$ & 0.416 & 0.431 & 0.452 & 0.457 & 0.451 & 0.446 & 0.428 & 0.439 \\
\hline$N_{4}, \%$ & 15.22 & 63.46 & 89.48 & 83.11 & 64.37 & 44.61 & 41.35 & 61.53 \\
\hline
\end{tabular}

$\psi_{B}=\frac{\left(\mathrm{Na}_{2} \mathrm{O}+\mathrm{K}_{2} \mathrm{O}+\mathrm{BaO}\right)+0.7(\mathrm{CaO}+\mathrm{SrO}+\mathrm{CdO}+\mathrm{PbO})+0.3\left(\mathrm{Li}_{2} \mathrm{O}+\mathrm{MgO}+\mathrm{ZnO}\right)-\mathrm{Al}_{2} \mathrm{O}_{3}}{\mathrm{~B}_{2} \mathrm{O}_{3}}$.

The values of structural factors $-f_{\mathrm{Si}}$ and $\psi_{B}$ (Table 2), theoretically indicate the high degree of structural strength of the MG 3 and MG 4. This is due to the quadruple coordination of $A l$ and preferably $B$, forming continuous aluminoborosilicate glass structure with localized on tetrahedral glass-modifiers cations $\mathrm{Na}^{+}, \mathrm{K}^{+}, \mathrm{Ca}^{2+}$, $\mathrm{Ba}^{2+}$. In the range of $1350-1400 \mathrm{~cm}^{-1}$ practically fixed peaks characteristic of $\left[\mathrm{BO}_{3}\right]^{3-}$. MG 1 is characterized by minimum index $\psi_{B}=0.14$, indicating that the boron in tetrahedral state of the glass structure. This is confirmed by presence of the corresponding peaks in the IR-spectra - Fig. 2.

As known, such glasses have low chemical resistance, which is due to their poor structural strength.
IR-spectroscopy confirmed the design assumptions of the basic glass-state coordination in the glass matrix. According to information received, investigated glass is characterized by a broad absorption band $(V)$ stretching vibrations $(v)$ 900-1200 $\mathrm{cm}^{-1}$ with a deep peak at $1030 \mathrm{~cm}^{-1}$, which indicates the high degree of polymerization of tetrahedra $\mathrm{SiO}_{4}$ (Fig. 2) [9, 11].

Besides of coordination state of glass former and extent of the silicon-oxygen skeleton connectivity, significant impact on the performance properties of glasses and glass coatings has capacity for modifying diffusion of cations, in particular $\mathrm{Na}^{+}$, depending on the density of atomic packing in the glass structure. In turn, diffusion of $\mathrm{Na}^{+}$is determined by its structural role in the glass network: 1) $\mathrm{Na}^{+}$stabilizes aluminum in tetrahedral coordination; 2) $\mathrm{Na}^{+}$takes 


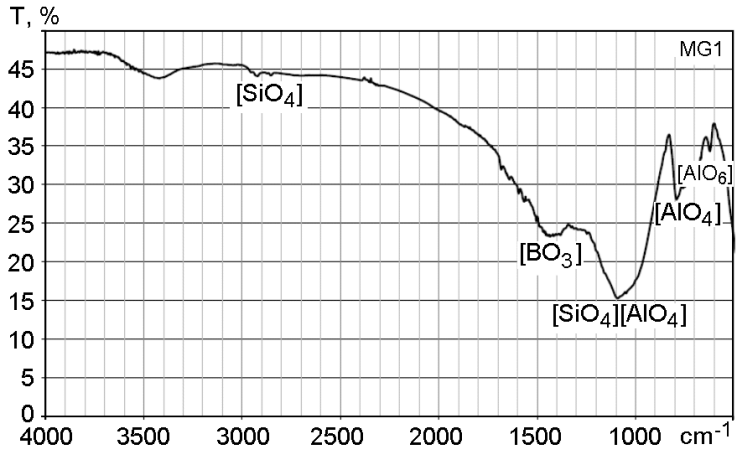

Fig. 2. IR-spectra of experimental model glass.

$\left[\mathrm{BO}_{3}\right]$ in $\left[\mathrm{BO}_{4}\right]$; 3) $\mathrm{Na}^{+}$forms unbridged oxygens $\left[\mathrm{SiO}_{4}\right]$ and / or $\left[\mathrm{BO}_{3}\right][12]$.

Atomic packing factor $A P F$ is the ratio between minimum theoretical amount that ions hold and corresponding molar amount of glass and it is calculated using the effective ionic radii, proposed by Shannon for the corresponding coordination numbers cations $(3)[12,13]$ :

$$
A P F=d \frac{\sum f_{i} V_{i}}{\sum f_{i} M_{i}},
$$

where for the $i$-th constituting formula $A_{x} B_{y}, d-$ density of glass, $f_{i}-$ mole fraction, $M_{i}-$ molar mass, $V_{i}=$ $(4 / 3) \cdot \pi \cdot N_{a} \cdot\left(x r^{3}{ }_{A}+y r_{B}^{3}\right)-$ theoretical volume, where $r_{A}$ and $r_{B}-$ ionic radii, and $N_{a}$ - the Avogadro's number.

The values obtained for $A P F$ model of glasses (Table 2) are correlated with indicators factor $\psi_{B}$. The glass MG 3, MG 4 are characterized by the highest degree of atomic packing with $A P F=0.452$ and 0.457 , respectively. This determines the weak diffusion of the modifier cations, and hence, their chemical resistance.

Chemical resistance of the experimental glasses, which are the basis of glass-coating for heating equipment, was determined and evaluated in accordance with the international standard ISO 28706:2008. On the basis of the results of the study of chemical resistance (Table 2) it was found that the MG 3 glass has the best characteristics.

Assessment of the modifiers diffusion degree, in particular $\mathrm{Na}^{+}$, was carried out using methods for determining the water resistance of the glass against tap and distilled water (flow rate $0.01 \mathrm{~N}$ of $\mathrm{HCl}$ solution in titration $V, \mathrm{~cm}^{3} \cdot \mathrm{g}^{-1}$ ) - Table 2 .
Determination of leaching of $\mathrm{Na}^{+}$indicates a decline in the diffusion of $\mathrm{Na}^{+}$to the growth ratio $\left[\mathrm{SiO}_{2}\right] /\left[\mathrm{Al}_{2} \mathrm{O}_{3}\right]$ and values $f_{\mathrm{Si}}$ and $\psi_{B}$. This trend can be explained by two reasons. Firstly, in the case of a relatively high content of $\mathrm{Al}_{2} \mathrm{O}_{3}$ (MG 1, MG 2, MG 7, MG 8) the $\mathrm{Na}^{+}$cations compensate the excess charge of groups $\left[\mathrm{AlO}_{4}\right]$ and $\left[\mathrm{BO}_{4}\right]$. In these glasses there is more intense diffusion of the ions modifiers, the reason of which is not their rigid fixing in the glass network, but localization in the tetrahedrons. At the low content of $\mathrm{Al}_{2} \mathrm{O}_{3}$, or at its absence (MG 3, MG 4, MG 5, MG 6) some of the cationsmodifiers create "unbridged oxygens" bound in the complexes through Si-O-R or B-O-R. In this case the ions-modifiers are less mobile. Secondly, the different structural state of boron, depending on chemical composition of the glass and determining the value $\psi_{B}$, causes the varying degrees of the nuclear glass packaging $A P F$ (Table 2). When the indicator values $\psi_{B}$ increases the structural mesh glass becomes more densely packed, making it difficult to diffusion of the cations-modifiers.

The results showed that in the alkali containing glasses diffusion of the cationsmodifiers reaches its maximum value when the charges of all the tetrahedrons $\left[\mathrm{AlO}_{4}\right]$ fully compensated oxygen donors, and in the glass structure the atoms are virtually absent "nonbridging oxygen" $\left(1 / 3 \leq \psi_{B} \leq 1\right.$ - MG 1 and MG 7). At higher content $\mathrm{R}_{2} \mathrm{O}$ value $\psi_{B}$ varies from 1 to 1.63 (for the MG 3 and MG 4), and the diffusion of cationsmodifiers is not increased, which positively influences on the chemical resistance of the glass - Table 2 . In this case, due to formation of a number of "nonbridging oxygen" the glass network structure is loosened, thereby improving its melting characteristics, namely reduction and melting temperature wetting. This dependence can be explained by the fact that the relations $\mathrm{R}-\mathrm{O}-\mathrm{Si}$ is stronger than the bond of the cation-modifier - a complex anion, whereby the amount of leached $R^{+}$is not increased (Table 2), and the melting characteristics are improved - Fig. 3.

Thus, the theoretical principles are confirmed $[10,14]$ about the aluminum being in fourfold coordination provided $\left[\mathrm{R}_{2} \mathrm{O}+\right.$ $\left.\mathrm{R}^{\prime} \mathrm{O}\right]>\mathrm{Al}_{2} \mathrm{O}_{3}$. Excessive amounts of the modifiers can be used to move $\left[\mathrm{BO}_{3}\right]$ to $\left[\mathrm{BO}_{4}\right]$ or to create "unbridged oxygens" from $\mathrm{Si}$ and $\mathrm{B}$ thermodynamic competition with these mechanisms. The proportion of 


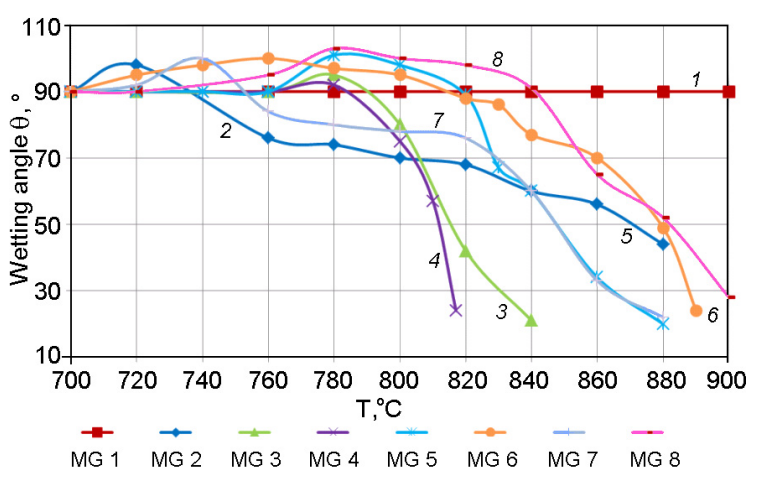

Fig. 3. Temperature dependences of wetting angle of melts of model glasses.

boron in the fourfold coordination with respect to its general content, i.e. the effective concentration of the modifier (the $N_{4}$ ), defined by the formula (4), reaches its maximum value, followed by the addition of the modifier, when the formation of "unbridged oxygens" becomes predominant. $N_{4}$ is controlled by excessive content of modifiers in the glass [15-18]:

$$
N_{4}=\frac{\left[\mathrm{R}_{2} \mathrm{O}\right]+[\mathrm{RO}]-\left[\mathrm{Al}_{2} \mathrm{O}_{3}\right]}{\left[\mathrm{B}_{2} \mathrm{O}_{3}\right]+\left[\mathrm{SiO}_{2}\right] \exp \left[-\Delta H / k T_{f}\right]},
$$

where $k$ - the Boltzmann constant; $T_{f}-$ fictitious temperature, it shall be equal to the glass transition temperature, $\Delta H$ - enthalpy difference between the two states.

Consequently, at the low concentrations there is a significant amount of $\mathrm{Al}_{2} \mathrm{O}_{3}$ modifiers used for transition of boron $\left[\mathrm{BO}_{3}\right]$ to $\left[\mathrm{BO}_{4}\right]$. In sodiumboroalumosilicate glasses the empirical models Della-Bray and DuStebbins are used to predict concentrations and $N_{4}$ "nonbridging oxygen" as functions of the glass composition [15, 16]. To apply this model, it is accepted $\left[\mathrm{R}_{2} \mathrm{O}\right]-\left[\mathrm{R}^{\prime} \mathrm{O}\right]$ as an effective concentration of the modifiers. When $\left[\mathrm{R}_{2} \mathrm{O}+\mathrm{R}^{\prime} \mathrm{O}\right]<\mathrm{Al}_{2} \mathrm{O}_{3}$, taken $N_{4}=0$, but in a series of such components investigated $\mathrm{MG}$ ratio is not used, i.e. for all windows $\left[\mathrm{R}_{2} \mathrm{O}+\mathrm{R}^{\prime} \mathrm{O}\right]>\mathrm{Al}_{2} \mathrm{O}_{3}$. For the models Della-Bray and Du-Stebbins the values $N_{4}$ exceed the experimental low content of $\mathrm{Al}_{2} \mathrm{O}_{3}$. This indicates that after charge compensation of $\left[\mathrm{AlO}_{4}\right]$ not all modifiers are used to transfer ions $\left[\mathrm{BO}_{3}\right]$ in $\left[\mathrm{BO}_{4}\right]$. A certain amount of them is used for other types of modification of the glass network, in particular for formation of the "nonbridging oxygen" on the tetrahedrons boron and silicon. The sodiumborosilicate glass is observed for the maximum values $N_{4}$ in various compositions where additional modifier

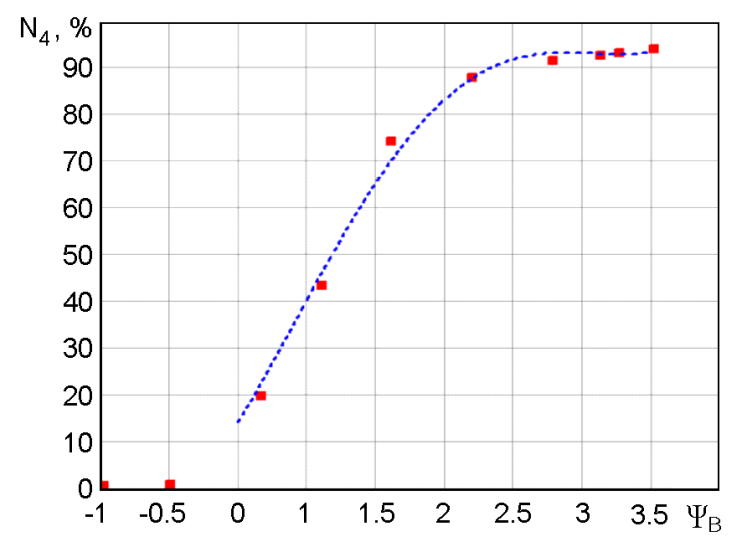

Fig. 4. Effective concentration of modifiers $N_{4}$, from $\psi_{B}$.

additive is used more to create the "nonbridging oxygen" instead of groups $\left[\mathrm{BO}_{4}\right]$. Therefore, even if the estimated $\psi_{B}=1$ the maximum value $N_{4}$ is not $100 \%$, but somewhat smaller. Provided $\mathrm{R}_{2} \mathrm{O}+\mathrm{R}^{\prime} \mathrm{O}>\mathrm{Al}_{2} \mathrm{O}_{3}$, the $N_{4}$ can be calculated as position of the highest values of chemical resistance of the glass, which is all aluminum in the fourfold coordination (or lack of), and under the condition $\mathrm{R}_{2} \mathrm{O}+\mathrm{R}^{\prime} \mathrm{O}-\mathrm{Al}_{2} \mathrm{O}_{3} \geq \mathrm{B}_{2} \mathrm{O}_{3}$ or $\psi_{B}=1$ is theoretically the entire boron goes into $\left[\mathrm{BO}_{4}\right]$. But experimentally it was determined the increase in chemical resistance of the model glass with increasing values of $\psi_{B}$ to 1.54 and 1.63 (compositions of the MG 3 and MG 4, respectively), i.e., to form the "nonbridging oxygen" quantity [15].

Using the models of Dell-Bray and DuStebbins and formula (4) it was determined the dependence of the effective concentration of the input modifier cations $N_{4}$, i.e. quantity formed the tetrahedral boron from values $\psi_{B}$ for alcaliboroalumosilicate system and it was set the values of indicator $N_{4}$ for the formulations of MG (Fig. 4, Table 2).

The data obtained (Table 2) indicate that an effective concentration of the modifiers $N_{4}$, i.e. the amount of generated tetrahedral boron in the experimental model glasses MG rises till values of $\psi_{B} \sim 1.6-1.8$. For the big values of $\psi_{B}$ on the graph in Fig. 4 the $N_{4}$ observed "playground" of constant values. When $\psi_{B}=1$, the effective concentration of the $N_{4}$ modifiers reaches only $65 \%$. It can be concluded that the effective concentration of the modifiers $N_{4}$ reaches its maximum at $90 \%$ values of $\psi_{B}$ being in the range from 1.5 to 1.8 , and further increase of the $\mathrm{R}_{2} \mathrm{O}$ and $\mathrm{R}^{\prime} \mathrm{O}$ content does not lead to the desired result. 


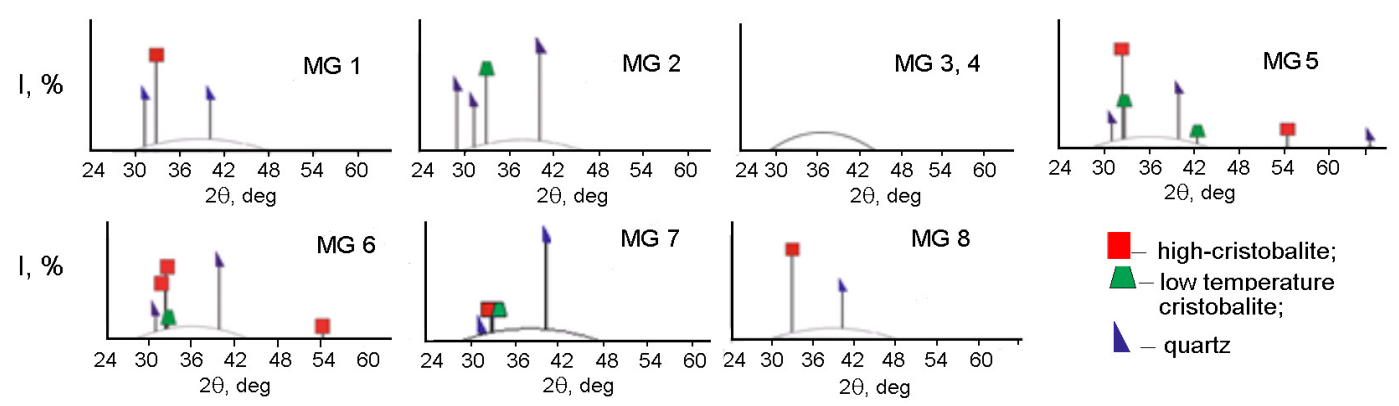

Fig. 5. Barcode XRD diffraction samples of model glasses.

Investigation of phase compositions of the MG samples obtained after coating firing at $T=840^{\circ} \mathrm{C}$ showed that in the MG 1 high-temperature cristobalite and quartz are intensively crystallized, in the MG $2-$ there are quartz and low temperature cristobalite, and slides in the MG 5, MG 6, MG 7 - there are cristobalite and quartz. According to the criteria for the direct-on coatings the formation of crystalline phases are undesirable. The compositions of the MG 3, MG 4 and MG 8 are characterized by $\mathrm{XRD}$, which is prerequisite for production of the coatings with the minimum value of internal stress, which contributes to accumulation of the crystalline phase formation in the firing process - Fig. 5 .

One criterion parameters of the developed glass frits intended for the production of the coatings by POESTA technology is the increased value of its specific resistivity. Therefore, in developing of the model glass compositions we used the ratio of the of alkali and alkaline earth metals oxides for providing the developing of polyalkalinic and polycationic effects. Manifestation of these effects causes the required values of the electrical own glasses $\rho \geq 10^{8} \Omega \cdot \mathrm{m}$. Resistance powders of the model glass was determined experimentally using the standard techniques [19]. Values of resistivity calculated by formula (5) are shown in Table 2:

$$
\rho=\frac{\pi \cdot d^{2} \cdot R_{v}}{4 \cdot L},
$$

where $d$ - diameter of electrodes, $\mathrm{m} ; L-$ the thickness of the layer of frit powder, $\mathrm{m}$; $R_{v}$ - volume resistivity powder, Ohms.

Summary data on the chemical composition of the model glasses and the corresponding properties and values of structural factors are given in Table 2.

\section{Conclusions}

Joint analysis of complex theoretical and experimental data shows the clear correlation of structural factors determining the state of the glass-coordination, coherence of the structure and the density of its packaging for model glasses in system $\mathrm{R}_{2} \mathrm{O}-\mathrm{R}^{\prime} \mathrm{O}-$ $\mathrm{Al}_{2} \mathrm{O}_{3}-\mathrm{B}_{2} \mathrm{O}_{3}-\mathrm{SiO}_{2}$ with their physical and chemical properties - chemical resistance, water resistance, surface tension and flowability, temperature characteristics. The study of the structure and modeling properties of the glasses found that the practical value of the structurally dependent performance properties, in particular, chemical resistance and water resistance does not correspond to the theoretical provisions about possible linked glass structure for the index structure factor $\psi_{B}=1$, since the effective concentration of the modifiers in this case it is only $65 \%$. This is due to formation of the "nonbridging oxygen", which determines the degree of softening of the glass structure, even with a lack of compensatory oxygen. For the fusible chemically resistant glass system in the study area it was defined the sharp boundaries of $\psi_{B}$ values ranging from 1.5 to 1.8 , corresponding to the maximum effective concentration of $N_{4}$ modifier at $90 \%$. The tendency to crystallize and refractory compositions of the MG increases with decreasing the $\psi_{B}$ values at constant content of $\mathrm{SiO}_{2}$ - the basic glass former.

Summarizing the results of the research, we can conclude that as the MFGM - the basis of fusible chemically resistant protective coatings applied for technology POESTA, it is advisable to select the MG 3 model glass composition, characterized by the high chemical resistance, the necessary values of coefficient of linear expansion, surface tension and its specific resistivity. 


\section{References}

1. L.L.Bragina, A.P.Zubehin, Ya.I.Belyiy et al., Tehnologiya Emali i Zaschitnyih Pokryitiy, NTU "HPI", Kharkiv (2003) [in Russian].

2. A.Pettsold, G.P.Yoshmann, Emal i Emalirovanie, Metallurgiya, Moscow (1991) [in Russian].

3. A.Dietzel, Emaillierung, Springer-Verlag, Berlin-New York (1981).

4. L.G.Hodskiy, Himicheski Ustoychivyie Stekloemali, Nauka i Tehnika, Minsk (1991) [in Russian].

5. Quality Requirements for Enamelled Hot Water Tanks (Boilers), Quality Requirements of European Enamel Authority, 4 Edition, DEV, Hagen (2013).

6. N.S.Kondakov, Metodyi Optimizatsii Eksperimenta $\mathrm{v}$ Himicheskoy Tehnologii, Moscow (1985) [in Russian].

7. O,V.Mazurin, Elektricheskie Svoystva Stekla, LTI, Leningrad (1962) [in Russian].

8. V.I.Goleus, A.Ya. Belyiy, T.I.Kozyireva et al., Fiz. Himiya Stekla, 17, 20 (1991).
9. A.A.Appen, Himiya Stekla, Himiya, Moscow (1974) [in Russain].

10. Y.M.Yaschishin, Tehnologiya Skla, Beskid BIt, Lviv (2008) [in Ukrainian].

11. I.I.Plyusnina, Infrakrasnyie Spektryi Mineralov, MGU, Moscow (1976) [in Russian].

12. M.M.Smedskjaer, Qiuju Zheng, J.C.Mauro et al., J. Non-cryst. Solids, No.357, 3744 (2011).

13. Acta Crystallographica. Section A. Crystal Physics, Diffraction, Theoretical and General Crystallography, v.32, Part 5, September (1976).

14. M.V.Artamonova, M.S.Aslanova, I.M.Buzhinskiy, Himicheskaya Tehnologiya Stekla i Sitallov, Stroyizdat, Moscow (1983) [in Russian].

15. Wan Junpeng, Cheng Jinshu, Lu Ping, $J$. Wuhan Univ. Techn, 3, 419 (2008).

16. J.F.Stebbins, F.Stebbins, L.S.Du, Z.Xu, NonCryst. Solids, 351, 3508 (2005).

17. Q.J.Zheng, R.E.Youngman, C.L.Hogue, Phys. Rev., No.86, 3 (2012).

18. L.S.Du, J.F.Stebbins, J.Non-Cryst.Solids, No.239. 315 (2003).

19. Pemco Enamel Manual, ed. by K.Lips, Pemco Brugge, Bruges (2008). 